\title{
Pemberdayaan Masyarakat Tani Melalui Pemanfaatan Tumbuhan Lokal Sebagai Pengendali Hama Ramah Lingkungan di Desa Padengo Kecamatan Popayato Barat
}

\author{
Mohamad Lihawa ${ }^{1}$, Angry P. Solihin ${ }^{2}$ \\ ${ }^{1}$ Fakultas Pertanian, Universitas Negeri Gorontalo, Jl. Jend. Sudirman No.6, Dulalowo Tim., \\ Kota Tengah, Kota Gorontalo, Gorontalo 96128, Indonesia \\ Email: mohammad.lihawa@ung.ac.id
}

\begin{abstract}
Abstrak
Kabupaten Pohuwato merupakan daerah penghasil jagung terbesar di Provinsi Gorontalo. Sejak tahun 2015, sekitar 50 persen produksi jagung di Provinsi Gorontalo berasal dari Kabupaten Pohuwato. Desa Padengo, Kecamatan Popayato Barat merupakan salah satu daerah yang berkontribusi dalam menghasilkan jagung di Kabupaten Pohuwato karena sebagian besar petani di desa ini adalah petani jagung. Berdasarkan hasil observasi dan wawancara dengan petani di desa Padengo diketahui salah satu permasalahan yang dihadapi petani jagung adalah sulitnya pengendalian hama ulat grayak pada jagung. Berdasarkan kondisi tersebut, program kuliah kerja nyata tematik melaksanakan pengabdian masyarakat tentang pemberdayaan masyarakat tani melalui pemanfaatan tumbuhan lokal sebagai pengendali hama ramah lingkungan. Pada program pengabdian ini telah dilakukan kegiatan seminar dan pelatihan pembuatan pestisida nabati bagi para petani, produksi pestisida nabati dari daun gulma siam dan daun gamal, aplikasi pestisida nabati pada lahan demonstrasi plot serta pengamatan populasi hama jagung secara berkala pada lahan jagung di desa Padengo Kecamatan Popayato Barat.
\end{abstract}

Kata kunci : Desa Padengo, jagung, hama, pestisida nabati

\begin{abstract}
Pohuwato Regency is the largest maize producing area in Gorontalo Province. Since 2015, about 50 percent of maize production in Gorontalo Province has come from Pohuwato Regency. Padengo Village, West Popayato District is one area that contributes to producing maize in Pohuwato Regency because most of the farmers in this village are maize farmers. Depend on the field observations and interviews with farmers in Padengo village, it is known that one of the problems faced by corn farmers is the difficulty of controlling armyworm pests in corn. Based on these conditions, the thematic real work lecture program carries out community service on empowering farming communities through the use of local plants as environmentally friendly pest controllers. In this community service program, seminars and training on the manufacture of vegetable pesticides have been carried out for farmers, production of vegetable pesticides from siam weed leaves and gamal leaves, application of vegetable pesticides on demonstration plots as well as regular observations of maize pest populations on maize fields in Padengo village, West Popayato District.
\end{abstract}

Keywords : Padengo village, maize, pest, botanical pesticides.

(C) 2019 Muhammad Kasim, Ahmad Zainuri Under the license CC BY-SA 4.0 Correspondence author: Mohamad Lihawa, mohammad.lihawa@ung.ac.id, Gorontalo, Indonesia 


\section{PENDAHULUAN}

Upaya meminimalisir serangan hama dan penyakit pada tanaman, dapat dilakukan dengan menerapkan pola pertanian yang baik. Pengendalian hama dan penyakit pada tanaman mengacu pada Peraturan Pemerintah Republik Indonesia Nomor 6 tahun 1995, yaitu bahwa tingkat produksi budidaya tanaman yang mantap sangat menentukan bagi keberhasilan usaha tani, sehingga segala bentuk kerugian yang dapat menurunkan tingkat produksi budidaya tanaman perlu dicegah atau ditekan serendah mungkin. Serangan organisme pengganggu tumbuhan terhadap tanaman dapat menimbulkan kerugian yang dapat mengganggu tingkat produksi budidaya tanaman, sehingga perlu ditempuh berbagai upaya untuk melindungi tanaman dari serangan organisme pengganggu tumbuhan. Upaya yang ditempuh untuk melindungi tanaman dari serangan organisme pengganggu tumbuhan harus dilakukan secara efektif dan aman agar tidak membahayakan keselamatan manusia, kemampuan sumberdaya alam maupun kelestarian lingkungan hidup, serta dapat mempertahankan dan meningkatkan produksi budidaya tanaman.

Berdasarkan data dari direktorat perlindungan tanaman pangan kementerian pertanian republik Indonesia, provinsi Gorontalo merupakan salah satu daerah penghasil jagung terbesar di Indonesia (Purnawan, 2020). Pada tahun 2018, total produksi jagung di provinsi Gorontalo mencapai 1,6 juta ton (Kementan, 2020). Hal ini menyebabkan tanaman jagung merupakan salah satu komoditas pertanian yang strategis di provinsi Gorontalo. Sejak tahun 2015 diketahui 50 persen produksi jagung diseluruh Provinsi Gorontalo berasal dari Kabupaten Pohuwato. Berdasarkan data tersebut, kabupaten Pohuwato merupakan daerah penghasil jagung terbesar di Provinsi Gorontalo.

Desa Padengo, kecamatan Popayato Barat merupakan salah satu desa yang berkontribusi dalam produksi jagung di Kabupaten Pohuwato. Hal ini disebabkan sebagian besar petani di desa ini adalah petani jagung. Desa padengo memiliki potensi pengembangan produksi jagung karena luas lahan yang dimanfaatkan sebagai lahan jagung baru mencapai 195 hektar, jauh dibandingkan dengan luas wilayah desa yang mencapai 21.000 Hektar. Disamping itu, desa Padengo dilalui oleh jalan trans sulawesi akan 
memudahkan proses transportasi dan perdagangan jagung baik di dalam provinsi Gorontalo maupun antar provinsi di pulau Sulawesi. Infrastruktur di desa padengo juga cukup memadai, yang meliputi sarana dan prasarana seperti jalan raya, jalan kebun, sekolah, tempat beribadah, gedung posyandu, puskesmas, lembaga pemerintahan, sarana prasarana lainya. Besarnya potensi lahan pertanian dan tersedianya infrastruktur di desa Padengo menjadikan desa ini sangat berpotensi menjadi salah satu sentra produksi jagung di Kabupaten Pohuwato dan Provinsi Gorontalo. Berdasarkan paparan yang dikemukakan diatas, maka kami melaksanakan program pengabdian masyarakat yang berjudul Pemberdayaan Masyarakat Tani Melalui Pemanfaatan Tumbuhan Lokal Sebagai Pengendali Hama Ramah Lingkungan di Desa Padengo, Kecamatan Popayato Barat, Kabupaten Pohuwato.

\section{METODE PELAKSANAAN}

Kegiatan pengabdian masyarakat ini dilakukan dengan beberapa metode yaitu observasi, penyuluhan, pelatihan serta demonstrasi plot. Seluruh kegiatan pemberdayaan ini ditujukan kepada para petani dan kelompok tani di desa Padengo, kecamatan Popayato barat agar dapat memiliki pengetahuan dan pemahaman tentang pemanfaatan tumbuhan lokal yang tumbuh secara liar sebagai bahan baku pembuatan pengendali hama yang ramah lingkungan.

Kegiatan ini dilaksanakan selama 45 hari yang dimulai pada tanggal 4 September 2020 hingga 18 September 2020. Bahan yang digunakan pada kegiatan ini adalah daun gulma siam (Chromolaena odorata), daun gamal (Gliricidia sepium), air serta deterjen bubuk. Alat yang digunakan pada kegiatan ini adalah gunting, pisau, parang, blender, ember, kayu, jerigen, tali rafia dan knapsack sprayer.

\section{HASIL DAN PEMBAHASAN}

Berdasarkan hasil observasi langsung kepada para petani jagung di desa Padengo diketahui terdapat beberapa permasalahan yang sering dihadapi oleh para petani jagung yaitu : 1) biaya produksi jagung yang cukup tinggi dan tidak sebanding dengan hasil yang diterima pada saat musim panen, 2) serangan hama dan penyakit yang terkadang bisa menurunkan hasil produksi khususnya 
tanaman jagung. Seperti contohnya hama yang sering mengganggu tanaman jagung; hama ulat tanah, ulat grayak, belalang, ulat penggerek batang/tongkol. Penyakit yang sering menyerang tanaman jagung; hawar daun, bulai dan lainlain, 3) ketidakmampuan pestisida kimiawi dalam penuntasan masalah hama yang sering dihadapi oleh masyarakat petani jagung desa Padengo, serta dalam penyediannya memerlukan biaya yang cukup besar.

Dari hasil inventarisasi masalah yang dihadapi oleh para petani jagung di desa Padengo maka kami melaksanakan beberapa program pemberdayaan yang bertujuan untuk membantu petani mengatasi permasalahanpermasalahan yang ada di lapangan, yaitu :

1) Seminar dan pelatihan pemanfaatan tumbuhan lokal sebagai pengendali hama

Pada tanggal 20 Septempber 2020 dilaksanakan program seminar dan pelatihan pemanfaatan tumbuhan lokal sebagai pestisida nabati pengendali hama pada tanaman jagung. Peserta dalam kegiatan ini adalah para petani yang mengelola lahan jagung di desa Padengo dan aparat desa. Pada kegiatan seminar dan pelatihan ini dibahas jenis-jenis organisme pengganggu tanaman, potensi tumbuhan lokal sebagai pestisida nabati pengendali hama serta pelatihan pembuatan pestisida nabati dari tumbuhan liar yang tersedia di desa Padengo. Bahan baku tumbuhan yang digunakan dalam pelatihan ini adalah daun gulma siam dan daun gamal. Hal ini disebabkan kedua tumbuhan ini yang paling banyak ditemukan di desa Padengo dan diketahui tidak dimanfaatkan oleh para warga masyarakat. Dalam kegiatan ini terungkap bahwa kendala yang dihadapi petani di desa Padengo saat ini adalah serangan ulat grayak jagung. Ulat grayak jagung ini diketahui menyerang tanaman jagung sejak berumur 2 minggu hingga jagung memasuki fase generatif.

Pada sesi pelatihan, para petani diperlihatkan cara pembuatan pestisida nabati dari daun gulma siam dan daun gamal untuk pengendali hama. Pelatihan ini mendapat respon yang cukup baik dari para petani yang mengikuti pelatihan, mengingat bahan baku dari pestisida ini cukup banyak tersedia di desa Padengo serta manfaat lain yang didapatkan juga cukup banyak diantaranya produk jagung akan lebih sehat karena tidak terpapar pestisida kimia serta 
dapat menurunkan biaya produksi bagi petani. Dokumentasi kegiatan seminar dan pelatihan disajikan pada gambar 1 .
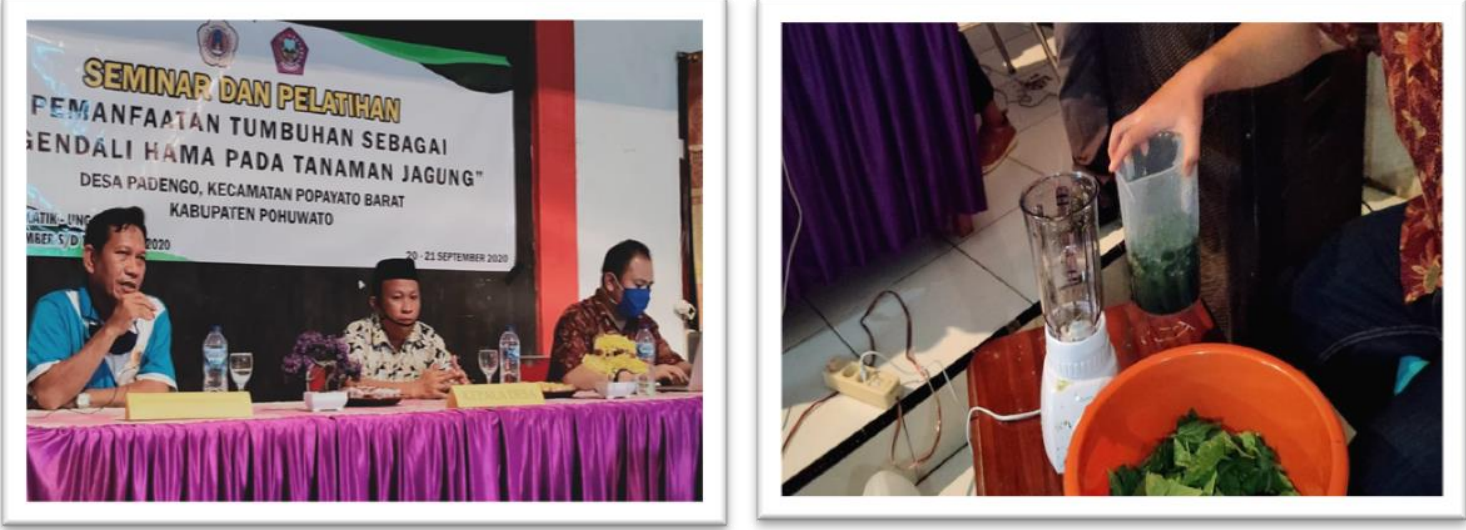

2) Pembuatan pestisida nabati dari gulma siam dan daun gamal

Setelah pelaksanaan seminar dan pelatihan bagi para petani, kegiatan KKN dilanjutkan dengan pembuatan pestisida nabati dari gulma siam dan daun gamal yang diperuntukkan bagi para petani dan akan diuji cobakan pada lahan jagung yang digunakan sebagai demonstrasi plot. Hal ini bertujuan agar para petani dapat melihat secara langsung efektivitas dari pestisida nabati dari ekstrak gulma siam dan daun gamal dalam mengendalikan hama pada tanaman jagung. Kegiatan pembuatan pestisida nabati dari gulma siam dan daun gamal ditampilkan pada gambar 2 .
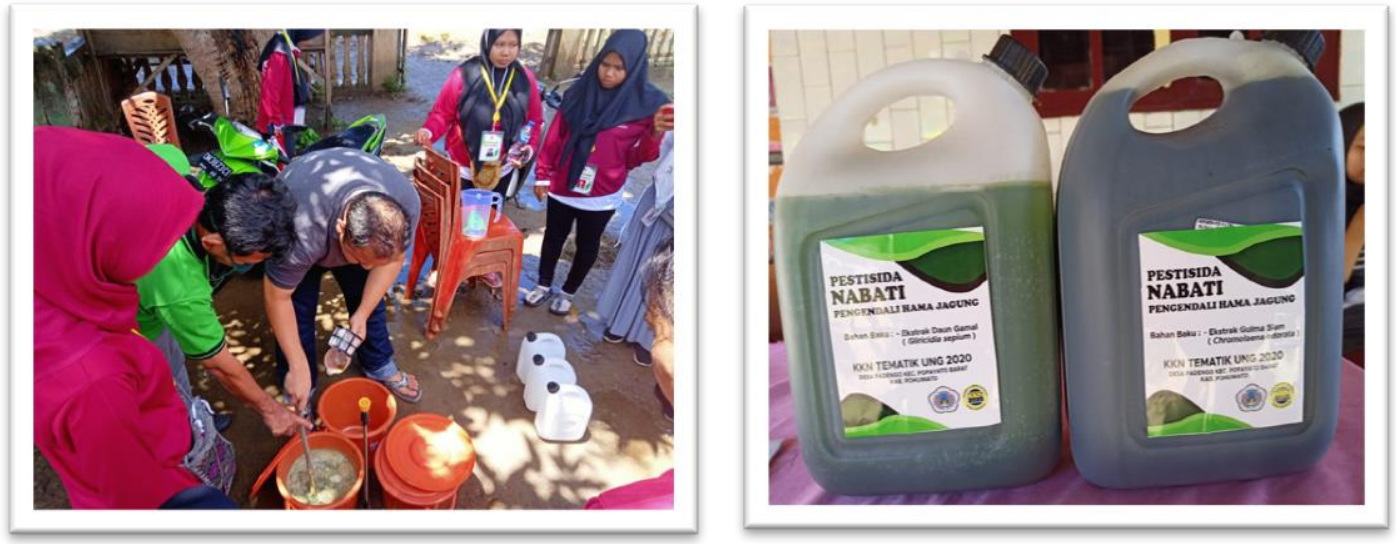

\section{Gambar 2. Pembuatan Pestisida Nabati dari Daun Gulma Siam dan Daun Gamal untuk Pengendali Hama}

Adapun cara pembuatan pestisida nabati dari daun gulma siam dan daun gamal adalah sebagai berikut : 
- 1 kilogram daun gulma siam dan daun gamal yang segar dicuci dengan air bersih dan dibersihkan dari bagian-bagian tanaman lain yang tidak diperlukan

- Daun gulma siam dan daun gamal dipotong kecil-kecil kemudian diblender atau ditumbuk dengan menambahkan air sedikit demi sedikit sampai halus

- Adonan daun gulma siam dan daun gamal yang telah halus kemudian dicampur dengan air hingga 1 Liter kemudian diaduk rata.

- Didiamkan selama satu malam/24 jam di dalam ember/wadah kemudian disaring ampasnya menggunakan saringan/kain tille

- Cairan yang sudah disaring diambil sebanyak $30 \mathrm{ml}$ untuk takaran 1 Liter air.

- Tambahkan deterjen bubuk secukupnya, kemudian dicampur dengan rata. Selanjutnya dapat disemprotkan pada tanaman jagung.

\section{3) Penyemprotan pestisida nabati pada lahan demonstrasi plot}

Kegiatan ini bertujuan untuk menguji efektivitas pestisida nabati gulma siam dan daun gamal yang telah dibuat serta sebagai salah satu cara untuk memberikan gambaran langsung kepada petani tentang dampak penggunaan pestisida nabati gulma siam dan daun gamal pada hama di pertanaman jagung. Lahan yang digunakan dalam kegiatan ini adalah lahan jagung milik petani yang tanamannya berumur kurang lebih 1 bulan.

Pada lahan demplot ini dibagi menjadi tiga bagian, satu bagian dilakukan aplikasi pestisida nabati gulma siam, satu bagian untuk aplikasi pestisida nabati daun gamal serta sisanya tidak diaplikasikan pestisida nabati. Tanaman jagung pada lahan demplot dilakukan penyemprotan dimulai dari bagian atas tanaman jagung hingga sampai pada batang bawah. Penyemprotan kembali dilakukan 1 minggu kemudian atau jika populasi hama jagung kembali meningkat. Aplikasi pestisida nabati pada lahan demonstrasi plot ditampilkan pada gambar 3 . 

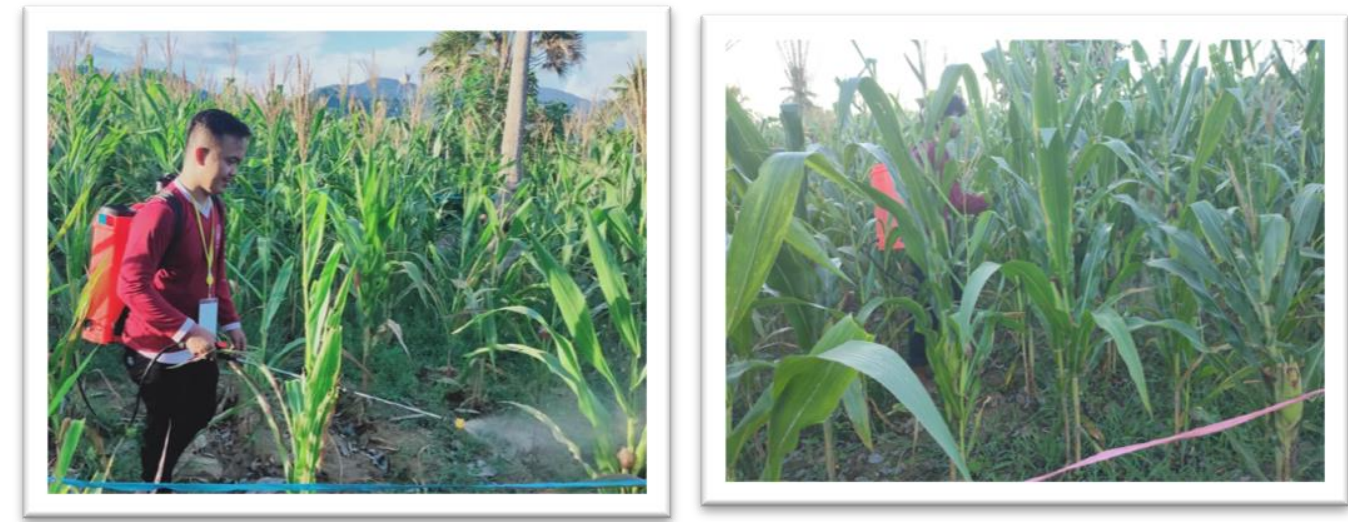

\section{Gambar 3. Penyemprotan Pestisida Nabati Gulma Siam dan Daun Gamal Pada Lahan Demonstrasi Plot}

\section{4) Pemantauan populasi hama}

Pemantauan populasi hama dilakukan pada lahan demplot yang telah diaplikasikan pestisida nabati gulma siam dan daun gamal. Kegiatan pemantauan ini dilakukan setiap minggu sekali setelah aplikasi pestisida nabati di lahan demplot (gambar 6). Pemantauan populasi hama bertujuan untuk memperoleh gambaran populasi hama pada lahan yang diamati. Kegiatan pemantauan populasi hama sangat penting dalam melakukan keputusan pengendalian yang akan dilakukan pada lahan/hamparan tanaman yang dibudidayakan.

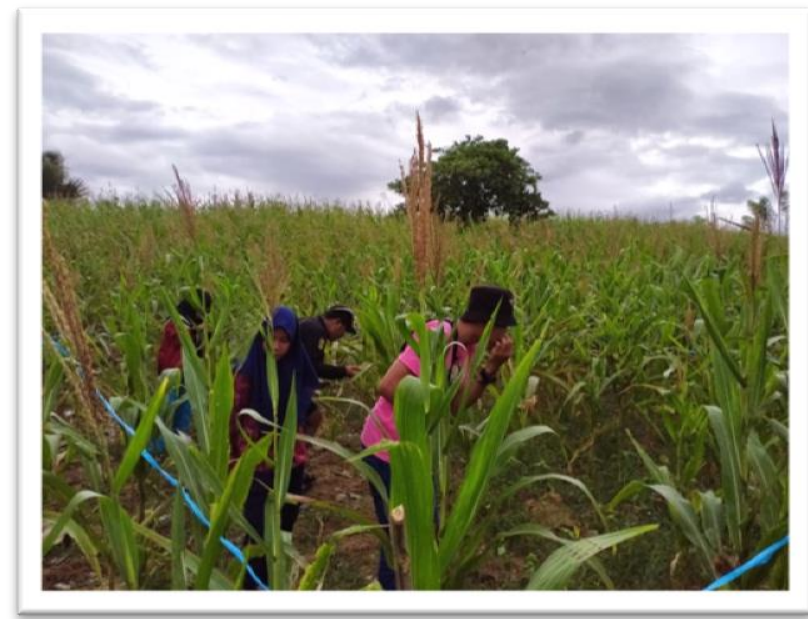

Gambar 4. Kegiatan Pemantauan Populasi Hama pada Lahan Demonstrasi Plot 


\section{KESIMPULAN}

Secara umum, pelaksanaan program Pemberdayaan Masyarakat Tani Melalui Pemanfaatan Tumbuhan Lokal Sebagai Pengendali Hama Ramah Lingkungan di Desa Padengo Kecamatan Popayato Barat di desa Padengo berhasil dengan baik dan tidak ditemukan hambatan yang berarti. Setelah kegiatan pemberdayaan dilaksanakan, para petani sangat antusias untuk menggunakan pestisida nabati dari gulma siam dan daun gamal dan akan menerapkannya di lahan jagung masing-masing. Hal ini disebabkan, gulma siam dan daun gamal yang banyak tumbuh liar di desa Padengo yang sampai saat ini tidak diketahui manfaatnya sehingga cenderung dibiarkan tumbuh dengan liar. Oleh sebab itu, para petani di desa Padengo merasa sangat terbantu dengan kegiatan pemberdayaan yang telah dilakukan.

Pada saat pelaksanaan kegiatan seminar dan pelatihan pemanfaatan tumbuhan sebagai pengendali hama, tidak semua perwakilan dari kelompok tani di desa Padengo dapat hadir. Hal ini disebabkan adanya kesibukan masing-masing petani pada saat kegiatan dilaksanakan serta vakumnya organisasi kelompok tani di desa Padengo hingga saat ini. Oleh sebab itu, perlu adanya koordinasi dan sosialisasi yang lebih baik kepada para kelompok tani untuk melaksanakan kegiatan pemberdayaan dikemudian hari.

\section{UCAPAN TERIMA KASIH}

Penulis mengucapkan terima kasih sebesar-besarnya kepada lembaga penelitian dan pengabdian kepada masyarakat (LPPM) Universitas Negeri Gorontalo yang telah mensupport dana pada kegiatan ini. Kami juga berterima kasih kepada seluruh aparat desa dan warga desa Padengo, kecamatan Popayato Barat, Kabupaten Pohuwato yang telah berkeja sama dan menerima dengan baik pelaksanaan program pemberdayaan ini.

\section{REFERENCES}

Kementerian Pertanian. 2019. Produksi Jagung menurut Provinsi tahun 20142018. Jakarta. 
Purnawan, E. 2020. Kebijakan Nasional Pengendalian Hama Ulat Grayak Jagung (Spodoptera frugiperda). Dipresentasikan pada Webinar Perhimpunan Entomologi Indonesia tanggal 13 Juni 2020. 